\title{
Using Supplemental Lighting to Control Flowering of Hops in Florida ${ }^{1}$
}

\author{
Shinsuke Agehara ${ }^{2}$
}

Hops (Humulus lupulus L.) are one of the emerging crops in Florida. Florida's craft beer industry has experienced significant growth over the last 10 years, with 285 breweries producing 42.6 million gallons of beer and generating an economic impact of $\$ 3.6$ billion in 2018 (Brewers Association 2018). To respond to their strong demand for locally grown hops, an interdisciplinary hops research team is currently studying optimum crop management practices for this emerging crop at the UF/IFAS Gulf Coast Research and Education Center (UF/IFAS GCREC). In Florida, the major yield-limiting factor is premature flowering induced by inadequate day length. This article provides guidelines for supplemental lighting to control flowering of hops in Florida.

\section{Introduction}

Hops are perennial, twining herbaceous plants in the Cannabaceae family. Hops are dioecious, meaning they have separate male and female plants. Female flowers produced on female hop plants develop into cones or strobiles, which are used for brewing to provide aroma and bitterness to beer.

Many plants use day length as an environmental cue to control the timing of flowering (Carré et al. 2018). Such plants are classified as short-day or long-day plants depending on if they flower when day length becomes shorter or longer than a specific number of hours, referred to as critical day length. In general, the critical day length for hops is 15 to 16 hours (Krebs 2019; Neve 1991). Hops are known as short-day plants (Thomas and Schwabe 1969) because they flower when day length drops below this threshold. The timing of blooming is a major yielddetermining factor. Hop plants are most productive when adequate vegetative bine (twining stem) growth is achieved by long day length before flowering is induced. Day length is a function of latitude, and the latitude range generally accepted for commercial hop production is $35^{\circ}$ to $55^{\circ}$ north or south of the equator (Dodds 2017). For example, the leading hop producing region in the United States is the Yakima Valley in Washington, where the latitude is $46.6^{\circ} \mathrm{N}$ and the longest day length is about 16 hours (National Oceanic and Atmospheric Administration 2019). In this region, hop plants promote adequate vegetative bine growth before flowering is induced.

In Florida, the latitude is below $31^{\circ} \mathrm{N}$, and the maximum day length is about 14 hours. Hop plants grown under this day-length condition tend to flower prematurely and thus have limited bine growth and cone yields. Artificial lighting is used commercially for many ornamental plants to regulate the timing of flowering (Morrow 2008). In our research hop yard at the UF/IFAS GCREC, we create a long-day condition ( $>17$ hours) using light-emitting diode (LED) lamps to induce vegetative bine growth to support higher yields, and simultaneously to prevent flowering during the early growing season (Figure 1).

1. This document is HS1365, one of a series of the Horticultural Sciences Department, UF/IFAS Extension. Original publication date April 2020. Visit the EDIS website at https://edis.ifas.ufl.edu for the currently supported version of this publication.

2. Shinsuke Agehara, assistant professor, Horticultural Sciences Department, UF/IFAS Gulf Coast Research and Education Center, Balm, FL 33598.

The Institute of Food and Agricultural Sciences (IFAS) is an Equal Opportunity Institution authorized to provide research, educational information and other services

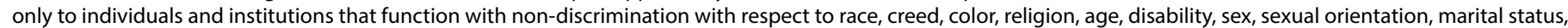

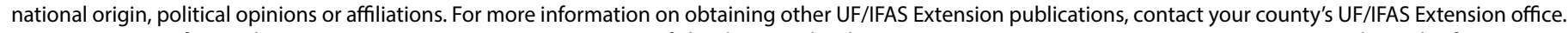
U.S. Department of Agriculture, UF/IFAS Extension Service, University of Florida, IFAS, Florida A \& M University Cooperative Extension Program, and Boards of County Commissioners Cooperating. Nick T. Place, dean for UF/IFAS Extension. 


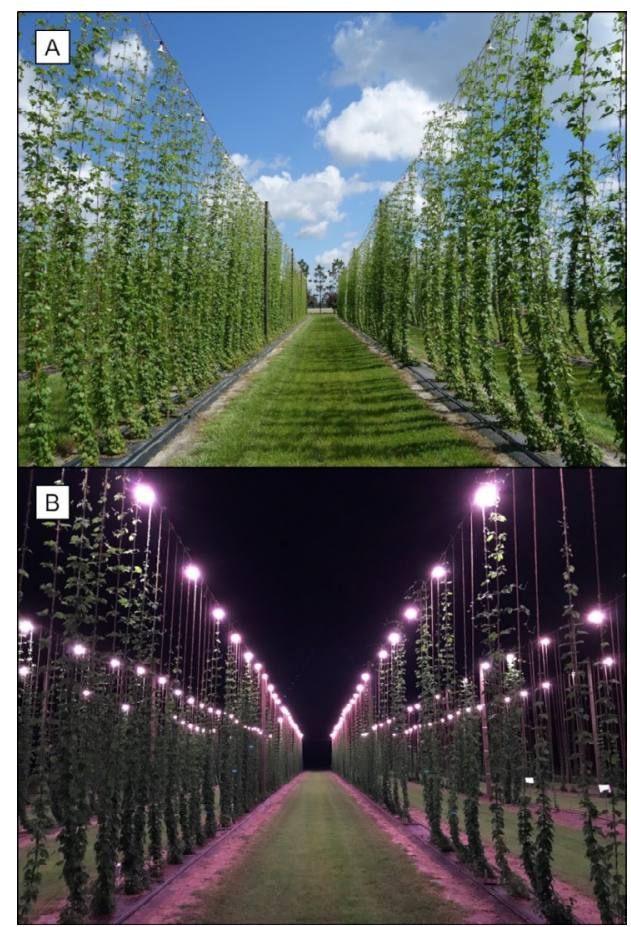

Figure 1. The UF/IFAS GCREC research hop yard in Balm, FL during the daytime (A) and at night (B).

Credits: Shinsuke Agehara, UF/IFAS

\section{Regulation of Flowering by Photoperiod Manipulation}

The regulation of flowering in response to day length or photoperiod is called photoperiodism. In photoperiodism, night length is actually more critical than day length (Koukkari and Sothern 2006). For example, short-day plants flower when night length is longer than the critical night length, and interrupting the night period can prevent them from flowering even under short-day conditions. Both photoperiod extension and night interruption are common practices used by greenhouse growers to inhibit flowering of short-day plants.

Four primary sources of artificial light are available for horticulture applications: incandescent, fluorescent, high-intensity discharge, and LEDs. The main advantage of LED technology compared to traditional light sources is the ability to control light spectral composition for specific applications (Morrow 2008). There are LED lamps developed specifically for the regulation of flowering (Meng and Runkle 2016). A spectrum rich in red light (600-700 $\mathrm{nm}$ ) is effective in inhibiting flowering of short-day plants, whereas adding far-red light $(700-800 \mathrm{~nm})$ to red light can promote flowering of long-day plants (Valverde et al. 2004). Far-red light alone does not regulate flowering of short-day plants (Craig and Runkle 2013).
It is important to choose the LED lamp that has the optimum light spectrum composition for your crop. To inhibit flowering of short-day plants, red light is generally sufficient, and adding high far-red light intensity is not desirable (Craig and Runkle 2013). However, there is substantial variation of spectral sensitivity among crops, so these rules do not apply in all cases. In our hop yard, we selected LED lamps that are not equipped with far-red light-emitting diodes.

It is also important to not confuse these "flowering" lamps with "grow" lamps that are used primarily to promote plant growth. Only very low-intensity light ( 1 to $2 \mu \mathrm{mol} / \mathrm{m}^{2} / \mathrm{s}$ ) is needed to regulate flowering, whereas 40 to $60 \mu \mathrm{mol} / \mathrm{m}^{2} / \mathrm{s}$ is generally needed to promote growth of ornamental plants (Meng and Runkle 2016).

\section{Regulation of Flowering in Hops by Photoperiod Extension \\ LED Lamps}

The LED lamps installed in our hop yard are the Philips GreenPower LED flowering lamps DR/W (Figure 2). There are two types of Philips GreenPower LED flowering lamps available: DR/W and DR/W/FR. The former is designed to inhibit flowering of short-day plants. The latter type contains far-red light as noted by "FR" in the specification, which is generally effective in promoting flowering of long-day plants.

Figure 3 shows the spectral distribution of the DR/W flowering lamp measured at the ground level, 19 feet directly below the lamp, by a spectroradiometer. The irradiance, or fluence rate, was only about $1 \mu \mathrm{mol} / \mathrm{m}^{2} / \mathrm{s}$, produced primarily by red light with very little far-red light. The fluence rate produced by this LED lamp is very low, considering that full sunlight can produce about $1,900 \mu \mathrm{mol} / \mathrm{m}^{2} / \mathrm{s}$ (Taiz and Zeiger 2010). However, it was still effective in preventing flowering and promoting vegetative bine growth (Figure 4). The maximum bine height was about $10 \mathrm{ft}$ without supplemental lighting, but it reached the top wire ( $18 \mathrm{ft}$ ) with supplemental lighting. Plants started developing flower buds within 5 days after lights were turned off.

\section{LED Lamp Installation Layout}

Figure 5 shows the LED lamp installation layout in our hop yard. We used commercial-grade light strands to install LED lamps (Figure 1B). The strands were tied on 18-foothigh main trellis cables (Figure 1A), and LED lamps were spaced 20 feet apart in a staggered pattern (Figure 5). This layout requires 138 lamps in a 1-acre hop yard. 


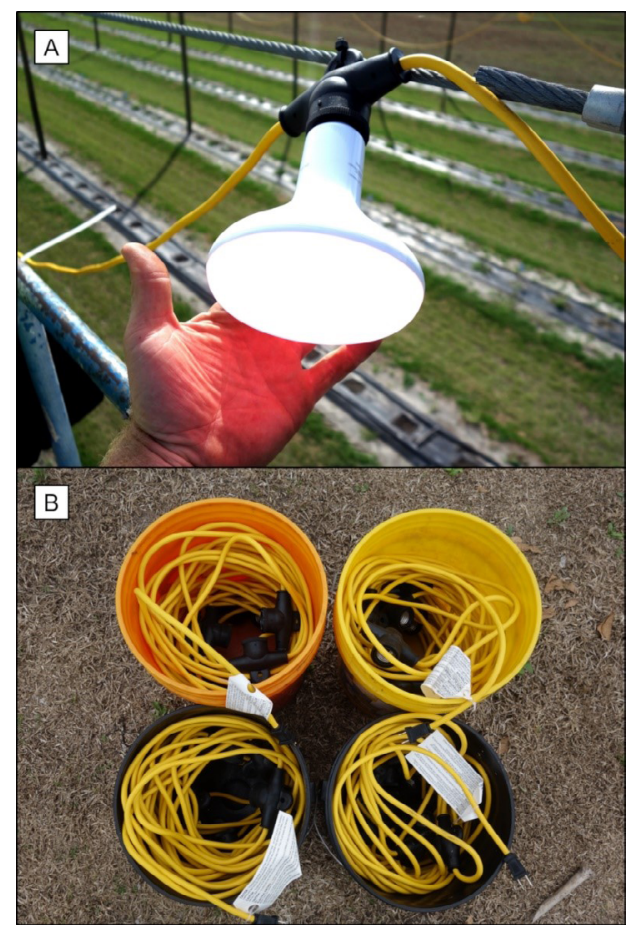

Figure 2. The Philips GreenPower LED flowering lamp DR/W (A) and light strands (B) used for the regulation of flowering in the UF/IFAS GCREC research hop yard in Balm, FL.

Credits: Shinsuke Agehara, UF/IFAS

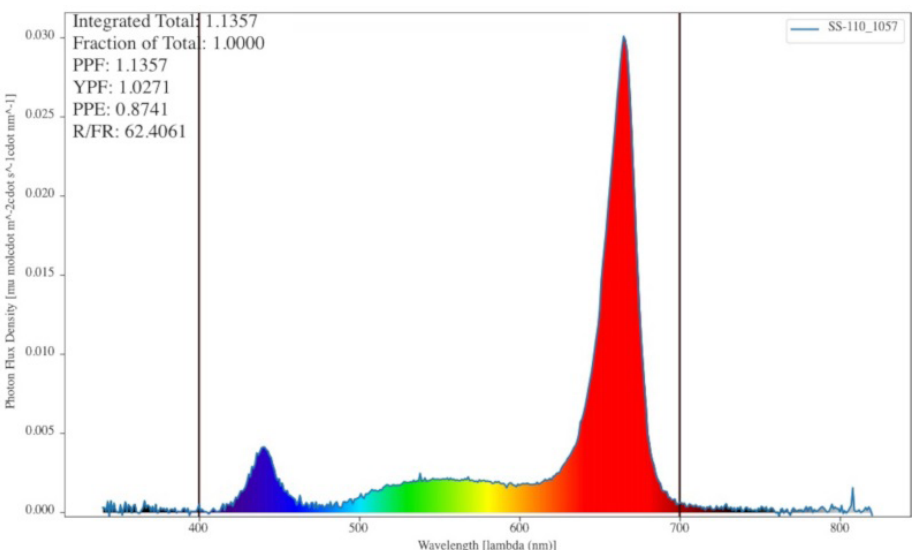

Figure 3. Light emission spectrum and intensity of the Philips GreenPower LED flowering lamp DR/W. The LED lamp was installed on a 19-ft-high trellis cable in the UF/IFAS GCREC research hop yard in Balm, FL. The measurement was performed at the ground level directly below the lamp using a spectroradiometer.

Figure 1B shows our hop yard illuminated by LED lamps at night. In this photograph, LED lamps were spaced 9 feet apart. However, we found that 20 -foot spacing is as effective as 9-foot spacing in preventing hop plants from flowering. We are currently testing wider lamp spacing to determine the minimum number of LED lamps required to inhibit flowering.
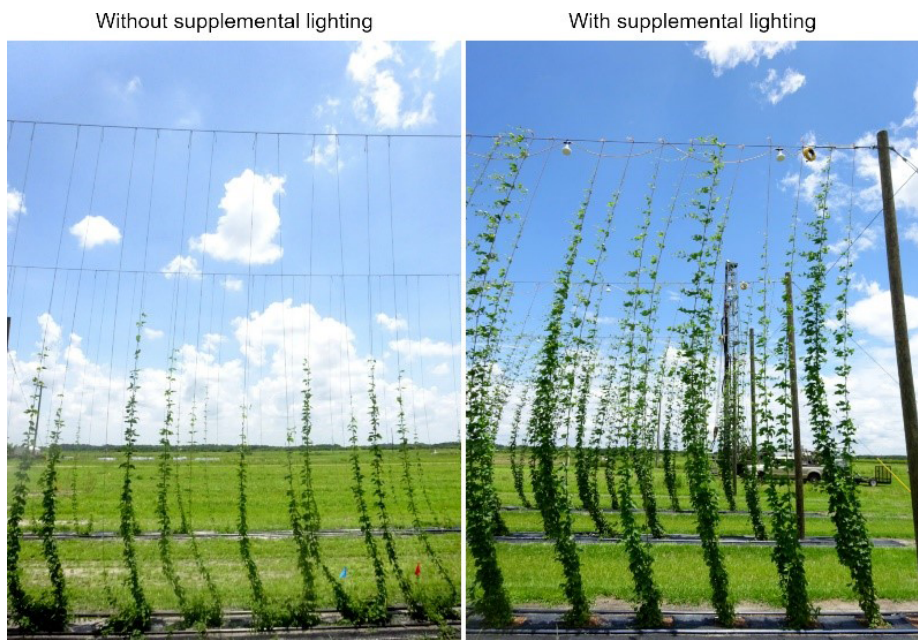

Figure 4. Bine growth of hops grown without (left) and with (right) supplemental lighting at the UF/IFAS GCREC research hop yard in Balm, FL. Photos were taken about 70 days after transplanting. The maximum bine height was about $10 \mathrm{ft}$ without supplemental lighting, but it reached the top wire $(18 \mathrm{ft})$ with supplemental lighting.

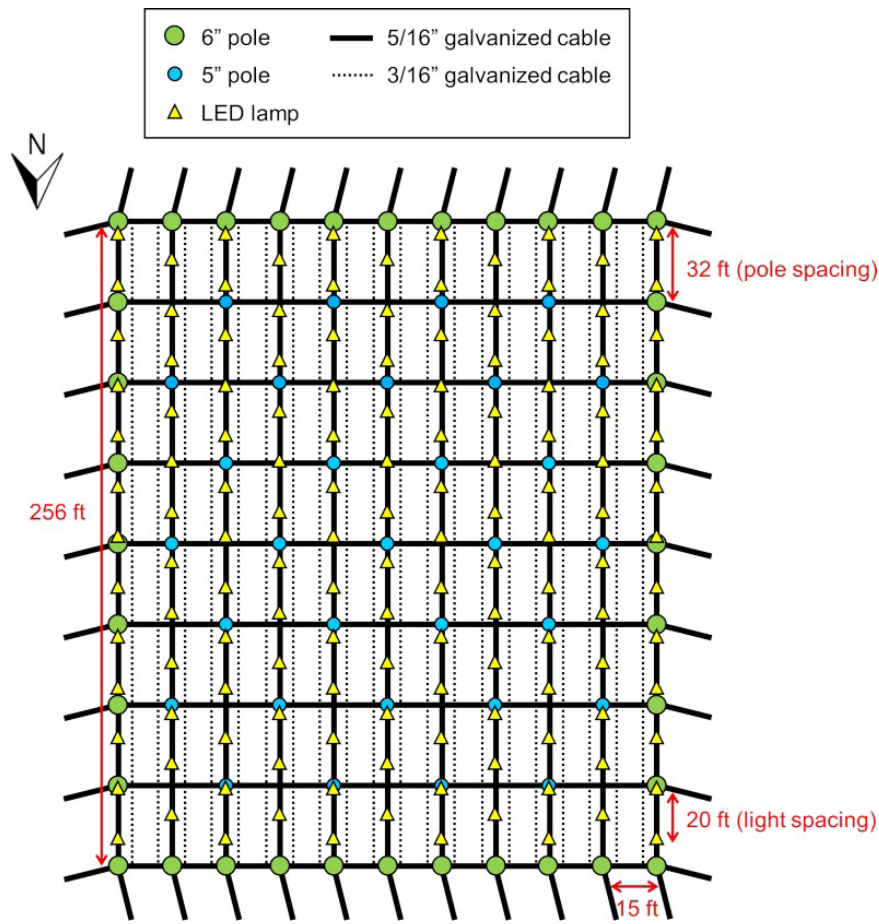

Figure 5. The LED lamp installation layout used in the UF/IFAS GCREC research hop yard in Balm, FL.

\section{Lighting Program}

We turn on LED lamps for 6 hours a day ( $>17$ hours of day length) over 7 to 9 weeks or until plants develop sufficient vegetative bine growth. Lamps are turned on at least 30 minutes before sunset. We use photoperiod extension rather than night interruption so we can check if the lighting system is functioning in the evening. Plants normally begin developing flower buds within five days after terminating photoperiod extension. 


\section{LED Lamp and Electricity Costs}

For our hop yard, costs for LED lamps and light strands were $\$ 3,209$ and $\$ 2,190$ per acre, respectively, totaling $\$ 5,399$ per acre. The installation cost can be significantly high depending on the availability of farm electricity supply (e.g., transformers).

The electricity cost is relatively low. In our 1-acre hop yard, there are 138 LED lamps, which operate at $13 \mathrm{~W}$ per lamp for 6 hours a day over 7 to 9 weeks in a growing season. The estimated electricity consumption in one growing season is 527 to $678 \mathrm{kWh}$. With the average electricity cost for the agricultural sector in Florida at $\$ 0.0758$ per $\mathrm{kWh}$ in August 2019 (US Energy Information Administration 2019), the estimated electricity cost in one growing season is $\$ 40$ to $\$ 51$ per acre.

\section{Literature Cited}

Brewers Association. 2018. "Florida's Craft Beer Sales and Production Statistics, 2018." Accessed April 13, 2020. https://www.brewersassociation.org/statistics-and-data/ state-craft-beer-stats/?state $=$ FL

Carré, I., G. Coupland, and J. Putterill. 2018. "Photoperiodic Responses and the Regulation of Flowering." Annual Plant Reviews online 21: 167-190.

Craig, D. S., and E. S. Runkle. 2013. "A Moderate to High Red to Far-Red Light Ratio from Light-Emitting Diodes Controls Flowering of Short-Day Plants." J. Amer. Soc. Hort. Sci. 138: 167.

Dodds, K. 2017. Hops: A Guide for New Growers. NSW Department of Primary Industries, New South Wales, Australia.

Koukkari, W. L., and R. B. Sothern. 2006. Introducing Biological Rhythms. Springer Science \& Business Media, Dordrecht, Netherlands.

Krebs, C. 2019. "Hops: A Viable Alternative Crop for the Central/Southern Plains?” Crops and Soils 52: 4-6.

Meng, Q., and E. Runkle. 2016. "Choosing the Right LEDs to Regulate Flowering in Greenhouses." 4 Aug. 2019. https://www.canr.msu.edu/news/ choosing_the_right_leds_to_regulate_flowering.

Morrow, R. C. 2008. "LED Lighting in Horticulture." HortScience 43: 1947-1950.
National Oceanic and Atmospheric Administration. 2019. "Sunrise/Sunset Calculator." 4 Aug. 2019. https://www.esrl. noaa.gov/gmd/grad/solcalc/sunrise.html.

Neve, R. A. 1991. Hops. Springer Science \& Business Media, Berlin, Germany.

Taiz, L., and E. Zeiger. 2010. Plant Physiology. 5th ed. Sinauer Associates, Inc., Sunderland, MA.

Thomas, G. G., and W. W. Schwabe. 1969. "Factors Controlling Flowering in the Hop (Humulus lupulus L.)." Ann. Bot. 33: 781-793.

US Energy Information Administration. 2019. "Electric Power Monthly." 14 Nov. 2019. https://www.eia.gov/electricity/monthly/epm_table_grapher.php?t=epmt_5_6_a.

Valverde, F., A. Mouradov, W. Soppe, D. Ravenscroft, A. Samach, and G. Coupland. 2004. "Photoreceptor Regulation of CONSTANS Protein in Photoperiodic Flowering." Science 303 (5660): 1003-1006. 